Metodički obzori 8(2013)1

UDK: 343.575-057.87:377.8(497.5Pula)

Preliminary notes

Primljeno: 17. 3. 2011.

\title{
EXPERIENCES AND REASONS FOR SUBSTANCES ABUSE AMONG THE STUDENTS ATTENDING THE DEPARTMENT OF PRIMARY EDUCATION AT THE UNIVERSITY OF PULA
}

\author{
dr. sc. Mirjana Radetić-Paić, \\ Sveučilište Jurja Dobrile u Puli \\ Odjel za obrazovanje učitelja i odgojitelja \\ e-mail: mradeticpaic@hotmail.com \\ dr. sc. Maja Ružić Baf, \\ Sveučilište Jurja Dobrile u Puli \\ Odjel za obrazovanje učitelja i odgojitelja \\ e-mail: maja@infosit.hr \\ Matija Medaković \\ Student učiteljskog studija \\ Sveučilište Jurja Dobrile u Puli
}

\begin{abstract}
Summary
This research's general aim is to get an insight into the experiences, reasons and differences in substances abuse by the the first to fourth-year students of the Department of Primary Education University of Pula $(\mathrm{N}=108)$ with the intention of planning prevention activities.

The results show that there are differences in experiences and reasons for substances abuse by students from different study years. Fourth-year students do not use ecstasy, but they have tried it because they wanted to experiment or out of boredom. They do not use heroin and they have not tried marijuana unlike students from other years. Such indicators show a relatively favourable situation of substances abuse among students from the oldest group of examinees, especially when it is the first-year students who have the furthest experiences and reasons from the ones mentioned.

This research's results give guidelines for prevention activities taking into consideration risk factors linked to substances abuse among students.
\end{abstract}

Key words: substances, students, abuse

\section{INTRODUCTION}

The addiction is the condition, sometimes psychical and sometimes physical, which appears as a consequence of the interaction between living organism and the drug and is characterized by changes in behaviour and other changes which include the compulsion of taking drugs again and again whether because of its positive 
effects or to escape from the suffering which will grow if they stop using it. The addiction is the condition which sometimes develops very fast, depending on the kind of a drug, its quantity and purity, frequency of consuming, the ways of taking it, the personality and the motivation of a consumer. Subsequently, some substances will cause physical and psychical addiction and some more emphasized psychical addiction (Sakoman, 1995).

The reasons which appeal young people to using substances of addiction could be different, from imitation, fashion, tendency to be accepted by the group of coevals, protest against the rules, curiosity etc. Some modern discoveries reveal that the substances abuse depends on deep personal problems which lead to the feelings of tension and anxiety trying to be reduced by drugs. There is pointed out in literature (Bortner, 1988; Boynton, 1988) that drug addicts posses under average sense of their own responsibility which leads to their failure, helpless feelings and the lack of self-confidence. If the person is younger, unstable, unsatisfied by itself or environment he or she lives in, and is experimenting with different substances her or his inside impulse to repeat it will arise faster and faster, self-control will faster relent and the habit of regular drug taking will be developed with the addiction itself. Bucher, $\mathrm{Vu}$ and Hojat (2012) find that $14 \%$ students reported that they had abused psychostimulant medications either before or during studing. Results of multivariate analysis of variance provided support for one of their research hypothesis: students who reported using psychostimulant compared to the rest, obtained a significantly higher average score on the aggressive-hostility personality factor.

On the other side, the large and expanded substances abuse market is in a constant search of new consumers and for it the young people with earlier mentioned characteristics during the process of growing up are just easy victims. Although there is mostly experimenting concerned, a part of those young people can't keep selfcontrol and continue taking such stuff which lead them to addiction and that brings an amount of hardly to be solved problems (Petak, 2005).

It is interesting but worrying that young people's opinion, which is relatively widely spread, supposes that in the period of experimenting with different subtances of addiction they could stop whenever they want to, with no chance to become addicts or that the act of substances abuse could affect their everyday functions or health.

Concerning the number of addicts, the city of Pula, compared by the number of inhabitants, is the second, following Zadar, in Republic of Croatia (www.uredza droge.hr). Well, it can be concluded that the different substances are easy to be reached in this area and there have been made numerous surveys in Pula (RadetićPaić, 2003., Radetić-Paić, 2005). Pula is specific because of different social, cultural, demographic, geographic, ethnic, economic, industrial and other characteristics reflected, by no doubt, on the young population.

When speaking about the surveys on this subject, the results in general show relatively small number of persons with the problem of substance abuse but it doesn't mean that the problem doesn't exist. Beside the problem of the hidden number, problem of substances abuse is probably being discovered too late and that fact indicates to the necessity of greater paying attention to it and acting to prevent it. 


\section{METHODOLOGY}

\section{The aim, purpose and hypothesis}

The main aim of this survey has been to research experiences and reasons for substances abuse in the group of students attending first to fourth year of Academic studies for Primary Education at the University of Pula, with the intention to plan the interventions of prevention.

The research has been based on several suppositions:

- The society we live in tolerates or even encourages the use of some substances of addiction. Before all, it refers to alcohol but also to the trade of other substances of addiction because of well spread crime market. And to the popularisation of positive effects on the consumer derived from some means of addiction.

- The young reach for the substances abuse because of different reasons. It is supposed that they use them because they have no possibilities to fulfil their free time by different (gratis) activities but also because of the problems they can't resolve by themselves.

- The students at third and fourth year of study will in all mentioned suppositions on supstances abuse give more mature answers and be more informed than younger students because they were given more pieces of information on negative aspects and consequences of different substances use during courses The pupils with behaviour disturbance and Pedagogy of children with difficulties in their development.

According to specific aims and suppositions there was set a hypothesis $\mathrm{H} 01$ there is no difference in experiences and reasons of substances abuse between the students from different years of Primary Education at the University of Pula.

As we don't have any results derived from the comparative surveys on this problem, our hypothesis was set as the zero-hypothesis.

\section{Examinee sample}

The sample $(\mathrm{N}=108)$ was composed of the students attending first, second, third and fourth year of Primary Education at the University of Pula. It consisted of female population mainly because the study is rather specific and there is a smaller number of male students. The sample was divided in four sub-samples: les

1. At first year of study 21 students were interrogated; 3 males and 18 fema-

2. At second year of study 28 students were interrogated ; 1 male and $27 \mathrm{fe}$ males

3. At third year of study 34 students were interrogated; 1 male and 33 females 

males

4. At fourth year of study 25 students were interrogated; 4 males and 21 fe-

\section{The sample of variables}

The query used was created just for the purpose of this research and consists of seven sections. The sections that are in relation with experiences and reasons of substances of addiction taking were used for this work. There are following variables involved:

Your experiences on use of mentioned supstances of addiction (No, I don't use, yes-tried, yes-rarely, yes/often):
a) Alcohol
b) Marijuana
c) Ecstasy
d) Heroin
e) Cocaine

Why did you try some of the substances of addiction?

a) Because of company I meet, they do it, I could do it

b) Because of personal problems ( University, love etc)

c) Because I'm bored

d) Just to try and see how does it affects me (experimenting)

e) Nothing mentioned, express why....

\section{Elaboration data methods}

Data were elaborated by calculating relative frequencies on observed query variables and discriminating analyses as multi-variable method of elaborating data which is a part of programme SPSS for Windows. A probability of error less than $5 \%$ was taken as a critical value of statistical signification.

\section{The way of procuring data}

Data were procured at the Department for Primary Education at the University of Pula year 2008, among the students attending all four years of Primary Education. Students filled up the query according the authors' instructions. The query was anonymous. 


\section{THE RESULTS AND DISCUSSION}

Table 1. gives the insight in students' experiences with certain substances of addiction. The answers are divided in four groups: NO (I don't use), YES (I tried it), YES (rarely), YES (often).

Table 1. Students' personal experiences connected to the use of substances of addiction.

\begin{tabular}{|c|c|c|c|c|c|c|c|c|}
\hline & \multicolumn{4}{|c|}{ first year of study } & \multicolumn{4}{|c|}{ second year of study } \\
\hline & $\begin{array}{c}\text { NO (I } \\
\text { don't } \\
\text { use) }\end{array}$ & $\begin{array}{l}\text { YES ( I } \\
\text { tried it) }\end{array}$ & $\begin{array}{c}\text { YES } \\
\text { (rarely) }\end{array}$ & $\begin{array}{l}\text { YES } \\
\text { (often) }\end{array}$ & $\begin{array}{c}\text { NO (I } \\
\text { don't } \\
\text { use) }\end{array}$ & $\begin{array}{l}\text { YES ( I } \\
\text { tried it) }\end{array}$ & $\begin{array}{c}\text { YES } \\
\text { (rarely) }\end{array}$ & $\begin{array}{l}\text { YES } \\
\text { (often) }\end{array}$ \\
\hline Alcohol & $4,8 \%$ & $28,6 \%$ & $52,4 \%$ & $14,3 \%$ & $3,6 \%$ & $14,3 \%$ & $50 \%$ & $32,1 \%$ \\
\hline Marijuana & $57,1 \%$ & $23,8 \%$ & $14,3 \%$ & $4,8 \%$ & $60,7 \%$ & $32,1 \%$ & $3,6 \%$ & $3,6 \%$ \\
\hline Ecstasy & $80,9 \%$ & $19 \%$ & $0 \%$ & $0 \%$ & $100 \%$ & $0 \%$ & $0 \%$ & $0 \%$ \\
\hline Heroin & $95,2 \%$ & $4,8 \%$ & $0 \%$ & $0 \%$ & $100 \%$ & $0 \%$ & $0 \%$ & $0 \%$ \\
\hline \multirow[t]{3}{*}{ Cocaine } & $100 \%$ & $0 \%$ & $0 \%$ & $0 \%$ & $100 \%$ & $0 \%$ & $0 \%$ & $0 \%$ \\
\hline & \multicolumn{4}{|c|}{ third year of study } & \multicolumn{4}{|c|}{ fourth year of study } \\
\hline & $\begin{array}{c}\text { NO (I } \\
\text { don't } \\
\text { use) }\end{array}$ & $\begin{array}{l}\text { YES ( I } \\
\text { tried it) }\end{array}$ & $\begin{array}{c}\text { YES } \\
\text { (rarely) }\end{array}$ & $\begin{array}{c}\text { YES } \\
\text { (often } \\
\text { ) }\end{array}$ & $\begin{array}{c}\text { NO }(I \\
\text { don't } \\
\text { use })\end{array}$ & $\begin{array}{l}\text { YES ( I } \\
\text { tried it) }\end{array}$ & $\begin{array}{c}\text { YES } \\
\text { (rarely) }\end{array}$ & $\begin{array}{c}\text { YES } \\
\text { (often ) }\end{array}$ \\
\hline Alcohol & $0 \%$ & $8,8 \%$ & $73,5 \%$ & $17,6 \%$ & $4 \%$ & $28 \%$ & $52 \%$ & $16 \%$ \\
\hline Marijuana & $52,9 \%$ & $29,4 \%$ & $17,6 \%$ & $0 \%$ & $48 \%$ & $40 \%$ & $8 \%$ & $4 \%$ \\
\hline Ecstasy & $88,2 \%$ & $11,8 \%$ & $0 \%$ & $0 \%$ & $76 \%$ & $20 \%$ & $0 \%$ & $4 \%$ \\
\hline Heroin & $97 \%$ & $2,9 \%$ & $0 \%$ & $0 \%$ & $96 \%$ & $4 \%$ & $0 \%$ & $0 \%$ \\
\hline Cocaine & $97 \%$ & $2,9 \%$ & $0 \%$ & $0 \%$ & $92 \%$ & $8 \%$ & $0 \%$ & $0 \%$ \\
\hline
\end{tabular}

The query demonstrated that $17,6 \%$ of students attending first, third and fourth year of study, often consume alcohol and those attending the third year of study show almost double thirst for it, almost $32,1 \%$. All observed students, except those from $3^{\text {rd }}$ year of study $(73,5 \%)$, answered that they (approximately $50 \%$ ) rarely consume alcohol.

Approximately 4 to $4,8 \%$ of students on first and fourth year of study often take marijuana.

The fact that some students of the first (4,8\%), third (2,9\%) and fourth year of study (4\%) had tasted heroin i.e. almost all substances of addiction is preoccupying.

The second group of questions (Table 2.) was aimed to the reasons of taking substances of addiction. The reasons why young people take drugs are various. Relatively small number of students answered that they took drugs because of companionship or problems in a family, love, university or similar causes (till 3, 5\%). Available surveys on students in Vukovarsko-Srijemska region have shown the opposite i.e. that friends are those factors which have a great influence (Bujišić, 
2006). The mentioned facts could indicate to particularities of each region in Republic of Croatia when speaking about addictions but also about the changes of reasons to take some substances during the period of five years.

The students at first year of study with $36,4 \%$, third with $32,4 \%$ and fourth with $32,1 \%$ answered that the reason for substances of addiction taking was boredom but those from the second year, 10,3\%, say the same. In general, the majority of answers referred to experimenting as the main reason of taking substances of addiction. There are relatively high indicators that, especially on fourth year of study, students see the reasons in something else. Reviewing each single query the answers referred to different opinions about tasting various substances of addiction (which could be explained as experimenting) but there are some opinions about the substances of addiction being beneficial.

Table 2. The reasons of using the means of addiction - relative frequencies

\begin{tabular}{|l|r|r|r|r|}
\hline & \multicolumn{1}{|c|}{$\begin{array}{c}\text { first } \\
\text { year of } \\
\text { study }\end{array}$} & $\begin{array}{c}\text { second } \\
\text { year of } \\
\text { study }\end{array}$ & $\begin{array}{c}\text { third } \\
\text { year of } \\
\text { study }\end{array}$ & $\begin{array}{c}\text { fourth } \\
\text { year of } \\
\text { study }\end{array}$ \\
\hline $\begin{array}{l}\text { a) Because of company I meet, they do it, } \\
\text { I could do it }\end{array}$ & $4,5 \%$ & $10,3 \%$ & $13,5 \%$ & $3,5 \%$ \\
\hline $\begin{array}{l}\text { b) Because of personal problems ( } \\
\text { University, love etc }\end{array}$ & $0 \%$ & $3,4 \%$ & $2,7 \%$ & $3,5 \%$ \\
\hline c) Because I'm bored & $36,4 \%$ & $10,3 \%$ & $32,4 \%$ & $32,1 \%$ \\
\hline $\begin{array}{l}\text { d) Just to try and see how does it affects } \\
\text { me (experimenting) }\end{array}$ & $36,4 \%$ & $65,5 \%$ & $40,5 \%$ & $25 \%$ \\
\hline e) Nothing mentioned, express why & $22,7 \%$ & $10,3 \%$ & $11 \%$ & $35,7 \%$ \\
\hline
\end{tabular}

Although the descriptive results showed that there were differences in experiences and reasons for using substances of addiction between the students from different years of study for Primary Education, to test set hypothesis a rough discriminatory analyses was done with the purpose to get insight the latent dimensions of those differences.

Table 3. Eigenvalues, Wilks' Lambdas and Significations

\begin{tabular}{|c|c|c|c|c|}
\hline Function & Eigenvalues & $\%$ of Variance & Cumulative \% & $\begin{array}{c}\text { Canonical } \\
\text { Correlation }\end{array}$ \\
\hline 1 &, 533 & 47,6 & 47,6 &, 590 \\
\hline 2 &, 358 & 31,9 & 79,6 &, 513 \\
\hline 3 &, 229 & 20,4 & 100,0 &, 432 \\
\hline $\begin{array}{c}\text { Test of } \\
\text { Function(s) }\end{array}$ & $\begin{array}{c}\text { Wilks' } \\
\text { Lambdas }\end{array}$ & Chi-square & df & Sig. \\
\hline 1 through 3 &, 391 & 88,292 & 66 &, 035 \\
\hline 2 through 3 &, 599 & 48,116 & 42 &, 239 \\
\hline 3 &, 814 & 19,373 & 20 &, 498 \\
\hline
\end{tabular}


Using discriminatory analyse on observed four groups of examinees, there were achieved three theoretically possible discriminatory functions in the space of variables describing experiences and reasons of taking substances of addiction. It is seen in Table 3. that only the first discriminating function is statistically significant at the level of $\mathrm{p}=.05$ and is discriminating monitored groups of examinees but it isn't possible to confirm initial hypothesis. Therefore, it could be concluded that there are differences in experiences and reasons of taking substances of addiction by students of different years of study at Primary Education.

The largest part in $1^{\text {st }}$ discriminatory function (Table 4.) occupies the variable I had no experience with ecstasy, I take the means of addiction just to see its effects (experimenting), I tried ecstasy, taking them because being bored, I don't use heroin and I tasted marijuana. The maximum correlation with $1^{\text {st }}$ discriminatory function have variables I don't use ecstasy, the means of addiction I take just to see its effects on me (experimenting) and I seldom use cocaine.

Analysing arithmetic means of groups at discriminating function (functions at group centroids) in Table 5., it is obvious that students at fourth had no experience with ecstasy, they take the means of addiction just to see their effects (experimenting), tried ecstasy, take the means of addiction because of boredom, don't use heroin and didn't try marijuana. On the other hand, previously mentioned experiences and reasons of taking substances of addiction are less characteristic for the students attending the first year of study.

Table 4. Standardized Canonical Discriminant Function Coefficients $(C)$ and Structure Matrix (S)

\begin{tabular}{|l|r|r|r|r|r|r|}
\hline \multicolumn{1}{|c|}{ Variable } & \multicolumn{1}{c|}{ C1 } & \multicolumn{1}{c|}{ S1 } & \multicolumn{1}{c|}{ C2 } & \multicolumn{1}{c|}{ S2 } & \multicolumn{1}{c|}{ C3 } & \multicolumn{1}{c|}{ S3 } \\
\hline expALKno &, 158 &, 032 &, 114 &,- 059 &,- 004 &,- 135 \\
\hline expALKtry &,- 429 &,- 223 &, 056 &,- 005 &,- 127 &,- 329 \\
\hline expALKrar &,- 148 &, 092 &, 276 &, 091 &, 313 &, 393 \\
\hline expALKoft &,- 320 &,- 073 & 1,260 &, 245 &, 749 &, 195 \\
\hline expMARno &,- 778 &, 205 & 1,038 &,- 099 & 1,017 &,- 120 \\
\hline expMARtry & $-1,028$ &,- 189 &, 872 &,- 036 &, 944 &, 023 \\
\hline expMARrar &, 000 &,- 073 &, 000 &, 245 &, 000 &, 195 \\
\hline expMARoft &,- 021 &,- 104 &,- 018 &,- 161 &,- 127 &,- 149 \\
\hline expEno & 2,487 &, 341 &,- 148 &,- 203 & 1,025 &,- 087 \\
\hline expEtry & 1,663 &,- 192 &,- 039 &, 304 & 1,047 &,- 149 \\
\hline expErar &, 123 &,- 104 &,- 323 &,- 161 &, 291 &,- 149 \\
\hline expEoft &, 667 &,- 244 &,- 258 &,- 027 &, 218 &,- 021 \\
\hline expHERno & 1,119 &, 140 &, 548 &,- 009 &,- 465 &,- 153 \\
\hline expHERtry &, 791 &, 129 &,- 277 &,- 110 &, 270 &, 223 \\
\hline expHERrar &, 432 &,- 121 &, 737 &, 019 & $-1,078$ &,- 059 \\
\hline expHERoft &, 000 &,- 244 &, 000 &,- 027 &, 000 &,- 021 \\
\hline expKOKno &, 015 &, 232 &,- 651 &,- 170 &, 794 &,- 141 \\
\hline expKOKtry &, 275 &, 027 &, 002 &, 238 &, 516 &, 195 \\
\hline expKOKrar &, 206 &,- 248 &,- 633 &,- 029 & 1,324 &, 143 \\
\hline expKOKoft &, 000 &,- 244 &, 000 &,- 027 &, 000 &,- 021 \\
\hline COMPANY &, 952 &, 190 &, 140 &,- 270 &,- 139 &, 002 \\
\hline PROBLEMS &, 479 &,- 048 &, 175 &,- 128 &,- 011 &, 044 \\
\hline BOREDOM & 1,313 &,- 101 & 1,031 &, 328 &, 189 &, 432 \\
\hline EXPERIMENT & 1,916 &, 278 &, 934 &,- 202 &,- 441 &,- 261 \\
\hline NOTHING &, 661 &,- 158 & 1,014 &, 463 &,- 543 &,- 296 \\
MENTIONED & & & & & & \\
\hline
\end{tabular}




\section{Table 5. Functions at Group Centroids}

\begin{tabular}{|c|c|c|c|}
\hline year of study & F1 & F2 & F3 \\
\hline 1. &,- 317 & $-1,038$ &, 426 \\
\hline 2. &,- 514 &, 716 &, 435 \\
\hline 3. &,- 336 & $-2,002$ &,- 657 \\
\hline 4. & 1,298 & 9,731 & 4,875 \\
\hline
\end{tabular}

\section{CONCLUSION}

What can we conslude and what can we do? On the basis of achieved indicators it could be concluded that there are differences in experiences and reasons of taking substances of addiction between students who attend different years of study at Primary Education at the University in Pula. Concerning the fourth year of study, when dealt with experiences in certain substances, it is characteristic that students don't use ecstasy but had tried it due to boredom and experimenting. As well, the fourth year doesn't use heroin and hasn't used marijuana as the others years did. These indicators show relatively positive image of the oldest group of examinees, differently from the first year which has the furthest experiences and reasons to use substances of addiction. It could be presumed that the higher level of maturity and the fact that they are better informed and educated through the studies held at University like courses Pupils with behaviour disorders and Pedagogy of children with development disorders than student at the first year of study. When speaking about the reasons that lead students to use supstances abuse it could be seen that the first year of study takes that substances for different reasons than students of the fourth year. It is presumed that they take substances because of the company they hang around with (my friends take it, I'll take it too...) but also because of incapability to resolve some of their personal problems. It is well known that the first year of study is for most students the year of adaptation to life of their own, adaptation to new duties and responsibilities and, on the other side, to life with less parent's control , frequent "hanging outs" and "mingling" but they aren't still mature enough and capable to cope the changes in their lifes.

The question is also: How to prevent all those behaviors on universities? Sznitman (2013) offers a new option. She has done researchers and practitioners a favour by examining the key issues involved in mandatory random student drug testing (MRSDT), as a controversial drug prevention strategy implemented widely in the United States. Sznitzman (2013) thinks the goals of drug testing are twofold: deterring student substance use by providing students with a reason to decline peers' drug offers and identifying individual students with substance use problems for referral to appropriate counselling/treatment services. While the first goal can be placed within universal drug prevention approaches aimed at the general student population, the second goal can be placed within selective prevention approaches that target individual students with increased risk of drug use problems. As a 
universal prevention approach, MRSDT shares the basic strategy of traditional universal school drug prevention strategies that aim to encourage students to 'just say no', and the underlying assumption that drug use is a function of individual susceptibility to peer pressure. Other results (Sznitman, Dunlop, Nalkur, Khurana, Romer, 2012; DuPont, Merlo, Arria, Shea, 2013) about drug testing also say that drug testing was associated with lower levels of personal substance use in positive school climates, but only for female students. There was no relationship between drug testing and male students' substance use. This results have to be discussed in terms of the importance of considering school climates before implementing drugtesting programs in high schools and rigorous long-term evaluations are needed to evaluate the effectiveness of various versions of drug testing programs to prevent drug use and identify students in need of assistance to become and stay drug-free.

But we need to be aware of the fact that students take different substances because of personal problems and characteristics. Some authors points (Johnston, O'Malley, Bachman Schulenberg, 2011) that those students who are not collegebound (a decreasing proportion of the total youth population) are considerably more likely to be at risk for using illicit drugs, drinking heavily, and particularly smoking cigarettes.

In our context, considering all of the above, the main role in phase of adaptation to the students' life and in prevention in the cases of substances abuse, is given to Students' associations and centers and Psychological counsel working at University in Pula (www.unipu.hr) but also to professors who could educate detect and diagnose addiction problems among their students. Also, in that context, Goverment of Croatia points the need of creation of addiction prevention programs for students on the univerities (Government of Croatia, 2012).

\section{LITERATURE}

Bortner, M.A. (1988), Delinquency and Justice. An Age of Crisis. McGrow-Hill Book Company. New York, London, Paris, Milano, Tokyo.

Boynton, D.R. (1988), Drug Addiction, Life Style Personality Factors and Psychopathology. Georgia. State University.

Bucher, J. T., Vu, D. M. and Hojat, M. (2012), Psychostimulant drug abuse and personality factors in medical students. Medical teacher. 35(1). 53-57.

Bujišić, G. (2006), Iskustva i stavovi o ovisnosti studenata vukoarskog Veleučilišta „Lavoslav Ružička“. Zbornik radova. Stručna konferencija s međunarodnim sudjelovanjem. Ovisnost, zlouporaba droga, rehabilitacija, resocijalizacija, smanjnje štete. Trendovi pristupi i odgovori društva na suzbijanje zlouporabe opojnih droga. Pula, 2006. 231-237.

DuPont R. L., Merlo L. J., Arria A. M., Shea C. L. (2013): Random student drug testing as a school-based drug prevention strategy. Addiction. 108 (5). 839845 . 
Johnston, L. D., O’Malley, P. M., Bachman, J. G., \& Schulenberg, J. E. (2011), Monitoring the future: National results on adolescent drug use: Overview of key findings, 2010. Ann Arbor, MI: Institute for Social Research, The University of Michigan.

Petak, O. (2005), Uloga Centra za socijalnu skrb u prevenciji ovisnosti. Zbornik radova: Stručna konferencija s međunarodnim sudjelovanjem «Borba protiv ovisnosti-borba za zdravu obitelj». Zagreb. 205-211

Radetić-Paić, M. (2003), Rizici i intervencije za djecu i mladež s poremećajima u ponašanju grada Pule. 6. znanstveni skup s međunarodnim sudjelovanjem Istraživanja u edukacijsko- rehabilitacijskim znanostima. Hrvatska revija za rehabilitacijska istraživanja. 39 (2). 223-233.

Radetić-Paić, M. (2005), Zloupotreba sredstava ovisnosti $i$ rizični čimbenici $u$ obiteljima djece i mladeći s poremećajima u ponašanju grada Pule. Zbornik radova: Stručna konferencija s međunarodnim sudjelovanjem «Borba protiv ovisnosti-borba za zdravu obitelj». Zagreb 132-140.

Sakoman, S. (2005), Doktore, je li istina da trava čisti pluća? SysPrint.Zagreb. 11. Sznitman, S.R. , Dunlop, S.M. Nalkur, P. Khurana, A.,Romer, D. (2012), Student Drug Testing in the Context of Positive and Negative School Climates: Results from a National Survey. Journal of Youth and Adolescence. 41 (2). 146-155.

Sznitman, S. R. (2013), Exploring the promise of mandatory random student drug testing by comparing it to other school drug prevention strategies. Addiction. 108 (5). 848-850.

www.unipu.hr - Studentske udruge i Psihološko savjetovalište - Sveučilište Jurja Dobrile u Puli, 20.12.2009.

www.uredzadroge.hr - Vlada Republike Hrvatske Ured za suzbijanje zlouporabe droga, 20.12.2009.

www.uredzadroge.hr/wp-content/uploads/2013/02/NAP_2012_2014_final.doc.pdf Nacionalni akcijski plan suzbijanja zlouporabe droga u Republici Hrvatskoj za razdoblje od 2012. do 2014., 30.06. 2013. 